\title{
Gambaran Faktor yang Berhubungan dengan Timbulnya Kejang Demam Berulang pada Pasien yang Berobat di Poliklinik Anak RS. DR. M. Djamil Padang Periode Januari 2010 - Desember 2012
}

\author{
Vivit Erdina Yunita, ${ }^{1}$ Afdal, ${ }^{2}$ Iskandar Syarif ${ }^{3}$
}

\begin{abstract}
Abstrak
Kejang demam merupakan kejang paling sering pada anak yang kemungkinan berulang. Pengetahuan tentang faktor yang berhubungan dengan kejang demam berulang perlu diketahui demi ketepatan tatalaksana. Tujuan penelitian ini adalah melihat gambaran faktor yang berhubungan dengan kejang demam berulang. Penelitian ini merupakan deskriptif dengan desain cross sectional. Jumlah sampel ditentukan dengan total sampling yaitu 40 pasien. Penelitian dilakukan dari Desember 2013 hingga Mei 2014. Data diambil dari berkas rekam medis pasien kejang demam berulang dari Januari 2010 sampai Desember 2012 di Poliklinik Anak RS. Dr. M. Djamil Padang. Variabel dependen adalah kejang demam berulang sedangkan variabel independen terdiri dari usia kejang demam pertama, jenis kelamin, riwayat kejang demam keluarga, riwayat epilepsi keluarga, dan tipe kejang demam pertama. Data yang diperoleh diolah dengan program komputer. Kejang demam berulang lebih banyak terjadi pada pasien yang kejang demam pertama pada usia 11 - 20 bulan (47,5\%), pasien perempuan (62,5\%), pasien dengan riwayat kejang demam keluarga $(72,5 \%)$, pasien tanpa riwayat epilepsi keluarga $(97,5 \%)$, dan kejang demam sederhana pada bangkitan kejang demam pertama (60\%). Sebagian besar kejang demam berulang terjadi pada pasien yang berusia $11-20$ bulan ketika kejang demam pertama, berjenis kelamin perempuan, memiliki riwayat kejang demam keluarga, tidak memiliki riwayat epilepsi keluarga, atau kejang demam sederhana pada bangkitan kejang demam pertama.
\end{abstract}

Kata kunci: faktor yang berhubungan, kejang demam berulang

\begin{abstract}
Recurrent febrile seizure is the most common seizure in young children. Although having good prognosis, it is very frightening for parents. Knowledge about recurrent febrile seizure is important to determine accuracy of treatment. The objective of this study was to describe knowledge about recurrent febrile seizures related to descriptive features. This descriptive cross sectional study was done in M. Djamil General Hospital by using medical record of recurrent febrile seizure from January 2010 to December 2012. Sample was 40 patients. Data was taken from 2013 December to 2014 May. Recurrent febrile seizures are dependent variable meanwhile age of initial seizure, sex, family febrile seizure history, family epilepsy history, and type of initial febrile seizure are independent variables. Collected data was proceed by using computer program. It was found that most patients who develop recurrent febrile seizures had their first attack in age of 11 - 20 months old (47.5\%), female sex (62.5\%), had febrile seizure family history (72.5\%), had no epilepsy family history (97.5\%), and had simple febrile seizure on their first attack (60\%). Most recurrent febrile seizure occur in 11 - 20 months old in age, female in gender, having family febrile seizure history, having no family epilepsy history, or had simple febrile seizure as the first attack.
\end{abstract}

Keywords: descriptive features, recurrent febrile seizure 
Affiliasi penulis: 1. Prodi Profesi Dokter FK UNAND (Fakultas Kedokteran Universitas Andalas Padang), 2. Bagian Anatomi FK UNAND, 3. Bagian IImu Kesehatan Anak FK UNAND.

Korespondensi: Vivit Erdina Yunita, Email:

viviterdinayunita26@gmail.com, Telp: 081364743894

\section{PENDAHULUAN}

Kejang demam didefinisikan sebagai bangkitan kejang yang terjadi pada kenaikan suhu tubuh (suhu rektal di atas $38^{\circ} \mathrm{C}$ ) yang disebabkan oleh proses ekstrakranium. Kejang demam merupakan kejang yang paling sering terjadi pada anak. ${ }^{1}$ Sebanyak $2 \%$ sampai $5 \%$ anak yang berumur kurang dari 5 tahun pernah mengalami kejang disertai demam dan kejadian terbanyak adalah pada usia 17-23 bulan. ${ }^{2}$ Secara umum kejang demam memiliki prognosis yang baik, namun sekitar 30 sampai 35\% anak dengan kejang demam pertama akan mengalami kejang demam berulang., ${ }^{2,3}$

Meskipun memiliki prognosis yang baik, namun kejang demam tetap menjadi hal yang menakutkan bagi orang tua. ${ }^{3}$ Untuk itu diperlukan pengetahuan tentang faktor-faktor yang mempengaruhi berulangnya kejang demam yang bisa diberikan kepada orangtua untuk meredakan ketakutan yang berlebihan dan kepentingan tatalaksana. ${ }^{3}$

Adanya faktor-faktor yang berhubungan dengan terjadinya kejang demam berulang adalah riwayat kejang demam dalam keluarga, usia kurang dari 12 bulan, temperatur yang rendah saat kejang, dan cepatnya kejang setelah demam. ${ }^{4}$ Selain empat faktor di atas, adanya faktor jenis kelamin, riwayat epilepsi dalam keluarga, dan kejang demam kompleks pada kejang demam pertama juga ditambahkan sebagai faktor prediktif kejang demam berulang. ${ }^{5}$

Tujuan penelitian ini adalah mengetahui faktor yang berhubungan dengan kejang demam berulang demi ketepatan tatalaksana.

\section{METODE}

Penelitian ini merupakan deskriptif dengan tinjauan retrospektif dengan menggunakan disain penelitian cross sectional yaitu variabel-variabel yang termasuk faktor risiko dan variabel yang merupakan efek diobservasi sekaligus pada waktu yang sama. Data yang diteliti berupa data sekunder dari rekam medis pasien yang didiagnosis kejang demam di Poliklinik Anak RS Dr. M. Djamil Padang.

Populasi adalah semua pasien yang berobat ke Poliklinik Anak RS Dr. M. Djamil Padang selama Januari 2010 - Desember 2012 dengan diagnosis kejang demam berulang pada lebih dari satu episode demam. Penelitian ini menggunakan total sampling di mana seluruh pasien kejang demam berulang pada periode Januari 2010 - Desember 2012 diambil sebagai sampel. Kriteria inklusi pada penelitian ini adalah usia antara 6 bulan -5 tahun, tidak mengalami gangguan neurodevelopmental sebelum bangkitan kejang demam pertama. Kriteria eksklusi ialah berkas rekam medis tidak ditemukan mengalami kelainan neurologis setelah kejang atau mendapatkan terapi profilaks kejang demam jangka panjang pada kejang demam sebelumnya.

Variabel penelitian ini adalah kejang demam berulang, usia saat kejang demam pertama, jenis kelamin, riwayat kejang demam dalam keluarga, riwayat epilepsi dalam keluarga, dan tipe kejang demam pertama yang dialami oleh pasien. Kejang demam berulang adalah kejang yang terjadi pada lebih dari satu episode demam. Kejang demam kompleks adalah kejang demam yang bersifat fokal, berlangsung lebih dari 15 menit, atau berulang dalam satu kali episode demam. Kejang demam sederhana adalah kejang demam yang bukan merupakan kejang demam kompleks.

Penelitian ini menggunakan berkas rekam medis pasien yang didiagnosis secara klinis menderita kejang demam di Poliklinik Anak RS Dr. M. Djamil Padang selama Januari 2010-Desember 2012.

Penelitian ini dilakukan di Poliklinik Anak RS DR. M. Djamil Padang dari bulan Desember 2013 hingga Mei 2014. Pengolahan data dilakukan secara komputerisasi.

\section{HASIL}

Pada kurun waktu Januari 2010 hingga Desember 2012 ditemukan 40 orang pasien yang mengalami kejang demam berulang. Hasil penelitian terhadap para pasien tersebut disajikan dalam tabeltabel berikut. 
Tabel 1. Distribusi frekuensi pasien kejang demam berulang berdasarkan usia pasien ketika mengalami kejang demam pertama

\begin{tabular}{lcc}
\hline $\begin{array}{l}\text { Usia Kejang } \\
\text { Pertama }\end{array}$ & Demam & $\%$ \\
\hline $1-10$ bulan & 17 & 42,5 \\
$11-20$ bulan & 19 & 47,5 \\
$21-30$ bulan & 3 & 7,5 \\
$31-40$ bulan & - & - \\
$41-50$ bulan & - & - \\
$51-60$ bulan & 1 & 2,5 \\
\hline Jumlah & 40 & 100 \\
\hline
\end{tabular}

Berdasarkan Tabel 1 dapat diketahui bahwa pada penelitian ini ditemukan hampir separuh kejang demam berulang terjadi pada pasien yang mengalami kejang demam pertama pada usia $11-20$ bulan, yaitu sebanyak 19 orang $(47,5 \%)$.

Tabel 2. Distribusi frekuensi pasien kejang demam berulang berdasarkan jenis kelamin

\begin{tabular}{lcc}
\hline Jenis Kelamin & $\mathbf{f}$ & $\%$ \\
\hline Perempuan & 25 & 62,5 \\
Laki-laki & 15 & 37,5 \\
\hline \multicolumn{1}{c}{ Jumlah } & 40 & 100 \\
\hline
\end{tabular}

Pada penelitian ini didapatkan bahwa lebih dari separuh kejang demam berulang terjadi pada pasien perempuan yaitu sebanyak 25 orang $(62,5 \%)$.

Tabel 3. Distribusi frekuensi pasien kejang demam berulang berdasarkan riwayat kejang demam dalam keluarga

\begin{tabular}{lcc}
\hline $\begin{array}{l}\text { Riwayat } \\
\text { demam } \\
\text { kelarga } \\
\text { dalam }\end{array}$ & $\mathbf{f}$ & $\%$ \\
\hline Ada riwayat & 29 & \\
Tanpa riwayat & 11 & 27,5 \\
\hline \multicolumn{1}{c}{ Jumlah } & 40 & 100 \\
\hline
\end{tabular}

Penelitian ini menemukan bahwa lebih dari separuh kejang demam berulang terjadi pada pasien yang memiliki riwayat kejang demam dalam keluarga yaitu sebanyak 29 pasien (72,5\%).
Tabel 4. Distribusi frekuensi pasien kejang demam berulang berdasarkan riwayat epilepsi dalam keluarga

\begin{tabular}{lcc}
\hline $\begin{array}{l}\text { Riwayat epilepsi } \\
\text { dalam kelarga }\end{array}$ & $\mathbf{f}$ & $\%$ \\
\hline Ada riwayat & 1 & 2,5 \\
Tanpa riwayat & 39 & 97,5 \\
\hline \multicolumn{1}{c}{ Jumlah } & 40 & 100 \\
\hline
\end{tabular}

Berdasarkan Tabel 4 dapat diketahui bahwa pada penelitian ini ditemukan lebih dari separuh kejang demam berulang terjadi pada kelompok pasien yang tidak memiliki riwayat epilepsi dalam keluarga yaitu sebanyak 39 orang $(97,5 \%)$.

Tabel 5. Distribusi frekuensi pasien kejang demam berulang menurut tipe kejang demam pertama yang dialami pasien

\begin{tabular}{lcc}
\hline $\begin{array}{l}\text { Tipe kejang demam } \\
\text { pertama }\end{array}$ & $\mathbf{f}$ & $\%$ \\
\hline Sederhana & 24 & 60 \\
Kompleks & 16 & 40 \\
\hline \multicolumn{1}{c}{ Jumlah } & 40 & 100 \\
\hline
\end{tabular}

Pada penelitian ini didapatkan bahwa lebih dari separuh kejang demam berulang terjadi pada pasien yang mengalami kejang demam sederhana pada kejang demam pertama yaitu sebanyak 24 pasien (60\%).

\section{PEMBAHASAN}

Faktor-faktor yang berhubungan dengan kejadian kejang demam berulang didapatkan dari kepustakaan meliputi usia pasien ketika mengalami kejang demam pertama, jenis kelamin pasien, riwayat kejang demam dalam keluarga pasien, riwayat epilepsi dalam keluarga pasien, tipe kejang demam pertama pada pasien, durasi demam sebelum bangkitan kejang demam pertama dan suhu tubuh pasien pada bangkitan kejang demam pertama. Durasi demam sebelum bangkitan kejang demam pertama dan suhu tubuh pada kejang demam pertama tidak tercantum dalam berkas rekam medis pasien maka pada penelitian ini kedua hal tersebut tidak dimasukkan. 
Kejang demam pertama pada usia 11 - 20 bulan ditemukan pada hampir separuh dari sampel yang diteliti. Hasil ini sama dengan penelitian sebelumnya yang juga dilakukan di RS dr. M. DJamil Padang yang menemukan bahwa angka kejadian kejang demam berulang ditemukan lebih tinggi pada kelompok usia yang lebih muda yaitu $\leq 12$ bulan. ${ }^{6} \mathrm{Hal}$ ini dikaitkan dengan dengan perkembangan otak anak. Anak di bawah usia satu tahun rentan terkena kejang demam karena pada usia ini otak anak sangat rentan terhadap peningkatan suhu tubuh yang mendadak. Pada usia 5 tahun, sebagian besar anak telah dapat mengatasi kerentanannya terhadap kejang demam. ${ }^{7}$

Pada penelitian ini ditemukan lebih dari separuh pasien berjenis kelamin perempuan. Hasil ini tidak sama dengan penelitian sebelumnya yang mendapatkan bahwa kejang demam berulang lebih banyak terjadi pada pasien dengan jenis kelamin lakilaki. $^{6} \quad$ Pertumbuhan dan perkembangan anak perempuan sedikit lebih cepat dibandingkan anak lakilaki. $^{8}$ Jika dihubungkan dengan hal ini maka seharusnya kejang demam berulang lebih sedikit terjadi pada anak perempuan karena kerentanannya terhadap kenaikan suhu lebih rendah dibandingkan anak laki-laki. Penulis menduga perbedaan ini diakibatkan oleh disain penelitian cross sectional yang digunakan, karena tidak mempertimbangkan adanya kemungkinan kasus di luar waktu penelitian yang ditetapkan. Berkemungkinan pada tahun yang peneliti anggarkan pada penelitian ini, pasien yang masuk cenderung lebih banyak pasien perempuan.

Ditemukan lebih dari separuh pasien kejang demam berulang yang memiliki riwayat kejang demam dalam keluarga (73,2\%). Hal ini dikaitkan dengan kepustakaan bahwa faktor genetik turut berperan dalam timbulnya kejang demam pada anak. Kejang demam diturunkan secara dominan autosomal sederhana sehingga banyak pasien kejang demam berasal dari orangtua yang pernah menderita kejang demam. ${ }^{2,9}$

Pada penelitian ini hanya ditemukan satu pasien kejang demam berulang (2,4\%) yang memiliki riwayat epilepsi dalam keluarga. Hasil ini hampir sama dengan penelitian sebelumnya yang justru tidak menemukan riwayat epilepsi pada seluruh kasus kejang demam berulang yang diteliti. ${ }^{6} \mathrm{Hal}$ ini dihubungkan dengan kepustakaan bahwa epilepsi bukanlah faktor prediktif kejang demam berulang, sebaliknya kejang demam dapat meningkatkan kemungkinan seorang anak untuk menderita epilepsi di masa depan. ${ }^{2,4}$

Terdapat 23 temuan pasien (56\%) kejang demam berulang yang mengalami kejang demam sederhana pada bangkitan kejang demam pertama. Hasil ini sama dengan penelitian sebelumnya yang juga mendapatkan kasus kejang demam berulang lebih tinggi pada pasien yang mengalami kejang demam sederhana pada kejang demam pertama. ${ }^{10}$ Jika dilihat dari manifestasinya, kejang demam kompleks berlangsung lebih lama daripada kejang demam sederhana dan berulang dalam satu periode demam maka trauma yang dialami neuron juga lebih berat sehingga kemungkinan untuk mengalami hal yang sama pada periode demam selanjutnya juga lebih tinggi. Perbedaan ini berkemungkinan disebabkan oleh disain penelitian yang digunakan. Di sini disain yang digunakan adalah cross sectional di mana peneliti tidak mempertimbangkan keadaan di luar waktu penelitian. Peneliti menduga pada waktu penelitian ini kasus yang banyak ditangani adalah pasien yang mengalami kejang demam sederhana pada bangkitan kejang demam pertama.

\section{KESIMPULAN}

Sebagian besar kejang demam berulang terjadi pada pasien yang mengalami kejang demam pertama pada usia 11 - 20 bulan.

Kejang demam berulang lebih banyak terjadi pada pasien dengan jenis kelamin perempuan.

Kejang demam berulang lebih banyak terjadi pada pasien yang memiliki riwayat kejang demam dalam keluarga.

Sebagian besar kejang demam berulang terjadi pada kelompok pasien yang tidak memiliki riwayat epilepsi dalam keluarga.

Kejang demam berulang lebih banyak terjadi pada pasien yang mengalami kejang demam sederhana pada kejang demam pertama. 


\section{DAFTAR PUSTAKA}

1. Johnston MV. Seizures in childhood. Dalam: Kliegman, Behrman, Jonson, Stanton, editor (penyunting). Nelson textbook of pediatrics. Edisi ke-18. United States of America: Elsevier; 2007. hlm. $2457-75$.

2. Soetomenggolo TS, Ismael $\mathrm{S}$, editor (penyunting). Buku ajar neurologi anak. Jakarta: Balai Penerbit Ikatan Dokter Anak.

3. Fetfeit A. Assesment of febrile seizures in children. Eur J Pediatr. 2007;(167):17 - 27.

4. Berg AT, Shinnar. Complex febrile seizures. Epilepsia. 1996:37(2):126 - 33.

5. Marudur PT, Herini ES, Satria CD. Predictive factors for recurrent febrile seizures. Paediatrica Indonesiana. 2012; 52(6):317 - 23.
6. Fitri. Gambaran faktor resiko berulangnya kejang demam pada anak di bangsal anak RSUP Dr. M. Djamil Padang periode Januari 1999 sampai dengan Desember 2000 (skripsi). Universitas Andalas; 2001.

7. Gilbert P. Penyakit yang lazim pada anak-anak: Arcan; 1995.

8. Rogol AD, Roemmich JN, Clark PA. Growth at Puberty. Elsevier Science. 2002; 31(6): $192-200$.

9. Hirtz DG. Febrile seizures. Pediatrics in review. 1997; 18(1): 5 - 9 .

10. Dewanti A, Widjaja JA, Tjandrajani A, Burhany AA. Kejang demam dan faktor yang mempengaruhi rekurensi. Sari Pediatri. 2012; 14(1): 57 - 61. 